\title{
Rapamycin impairs metabolism-secretion coupling in rat pancreatic islets by suppressing carbohydrate metabolism
}

\author{
Makiko Shimodahira, Shimpei Fujimoto, Eri Mukai, Yasuhiko Nakamura, Yuichi Nishi, Mayumi Sasaki, \\ Yuichi Sato, Hiroki Sato, Masaya Hosokawa, Kazuaki Nagashima, Yutaka Seino ${ }^{\mathbf{1}}$ and Nobuya Inagaki \\ Department of Diabetes and Clinical Nutrition, Graduate School of Medicine, Kyoto University, 54 Shogoin Kawahara-cho, Sakyo-ku, Kyoto 606-8507, Japan \\ ${ }^{1}$ Kansai Electric Power Hospital, Osaka 553-0003, Japan \\ (Correspondence should be addressed to S Fujimoto; Email: fujimoto@metab.kuhp.kyoto-u.ac.jp)
}

\begin{abstract}
Rapamycin, an immunosuppressant used in human transplantation, impairs $\beta$-cell function, but the mechanism is unclear. Chronic (24 h) exposure to rapamycin concentration dependently suppressed $16.7 \mathrm{mM}$ glucose-induced insulin release from islets $(1 \cdot 65 \pm 0 \cdot 06,30 \mathrm{nM}$ rapamycin versus $2 \cdot 35 \pm 0 \cdot 11 \mathrm{ng} /$ islet per $30 \mathrm{~min}$, control, $n=30, P<0 \cdot 01)$ without affecting insulin and DNA contents. Rapamycin also decreased $\alpha$-ketoisocaproate-induced insulin release, suggesting reduced mitochondrial carbohydrate metabolism. ATP content in the presence of $16.7 \mathrm{mM}$ glucose was significantly reduced in rapamycin-treated islets $(13.42$ $\pm 0 \cdot 47$, rapamycin versus $16 \cdot 04 \pm 0 \cdot 46 \mathrm{pmol} /$ islet, control, $n=30, \quad P<0 \cdot 01)$. Glucose oxidation, which indicates the velocity of metabolism in the Krebs cycle, was decreased by rapamycin in the presence of $16.7 \mathrm{mM}$ glucose $(30 \cdot 1 \pm 2 \cdot 7$, rapamycin versus $42 \cdot 2 \pm 3 \cdot 3 \mathrm{pmol} /$ islet per $90 \mathrm{~min}$, control,

$n=9, P<0 \cdot 01)$. Immunoblotting revealed that the expression of complex I, III, IV, and V was not affected by rapamycin. Mitochondrial ATP production indicated that the respiratory chain downstream of complex II was not affected, but that carbohydrate metabolism in the Krebs cycle was reduced by rapamycin. Analysis of enzymes in the Krebs cycle revealed that activity of $\alpha$-ketoglutarate dehydrogenase (KGDH), which catalyzes one of the slowest reactions in the Krebs cycle, was reduced by rapamycin $(10 \cdot 08 \pm 0 \cdot 82$, rapamycin versus $13 \cdot 82$ $\pm 0.84 \mathrm{nmol} / \mathrm{mg}$ mitochondrial protein per min, control, $n=5, P<0 \cdot 01)$. Considered together, these findings indicate that rapamycin suppresses high glucose-induced insulin secretion from pancreatic islets by reducing mitochondrial ATP production through suppression of carbohydrate metabolism in the Krebs cycle, together with reduced KGDH activity. Journal of Endocrinology (2010) 204, 37-46
\end{abstract}

\section{Introduction}

Rapamycin, an immunosuppressant used in human organ and tissue transplantation, exhibits a different mechanism of action from that of cyclosporine, tacrolimus, and corticosteroids. The agent is a macrolide that prevents T-cell activation through its inhibitory effect on serine/threonine kinase, the mechanistic target of rapamycin (MTOR). The insulin- and nutrient-signaling pathway through MTOR plays an important role in initiation of protein translation, a critical event in enhanced protein synthesis that leads to increased cell cycle progression and proliferation (McDaniel et al. 2002).

Brittle type 1 diabetes has been successfully treated by human islet transplantation using the Edmonton protocol, which includes use of rapamycin as an immunosuppressant (Shapiro et al. 2000). Some studies suggest rapamycin may be diabetogenic ( $\mathrm{Lu}$ et al. 1994, Teutonico et al. 2005), and the effects of rapamycin on glucose homeostasis have been investigated. In skeletal muscle cells, long-term exposure to rapamycin decreases insulin-dependent uptake of glucose and glycogen synthesis and increases fatty acid oxidation
(Sipula et al. 2006). Rapamycin also decreases insulin-mediated glucose uptake and insulin signaling in adipocytes (Taha et al. 1999, Cho et al. 2004). Interestingly, rapamycin both prevents $\beta$-cell mass expansion and impairs $\beta$-cell function (Bell et al. 2003, Zhang et al. 2006, Fraenkel et al. 2008).

In pancreatic $\beta$-cells, intracellular glucose metabolism regulates exocytosis of insulin granules according to metabolism-secretion coupling in which glucose-induced mitochondrial ATP production plays an essential role (Maechler \& Wollheim 2001). Since depletion of mitochondrial DNA abolishes the glucose-induced ATP elevation, mitochondria clearly are a major source of ATP production in pancreatic $\beta$-cells (Kennedy et al. 1998, Tsuruzoe et al. 1998). Glucose-induced insulin secretion from $\beta$-cells is often impaired due to reduced glucoseinduced ATP elevation by exposure to high concentrations of fuels including glucose, free fatty acids, and ketone body, and by administration of diabetogenic pharmacological agents (Fujimoto et al. 2007). Thus, reduced mitochondrial ATP production plays an important role in impaired glucoseinduced insulin secretion. 
Recently, several reports have shown that inhibition of MTOR by rapamycin decreases mitochondrial oxidative function using various materials including kidney mitochondria (Simon et al. 2003), Jurkat cells (Schieke et al. 2006), and skeletal tissue and cells (Cunningham et al. 2007). We investigated the effects of chronic exposure to rapamycin on metabolism-secretion coupling, especially on glucose metabolism in mitochondria, in pancreatic $\beta$-cells.

\section{Materials and Methods}

\section{Materials}

Rapamycin was purchased from Calbiochem (La Jolla, CA, USA). Disodium succinate, rotenone, pyruvate potassium, malate, and tetramethyl-p-phenyldiamine (TMPD) were purchased from Nacalai (Kyoto, Japan). Mouse monoclonal antibody to the subunits of the mitochondrial respiratory chain complex was obtained from Invitrogen. $\left[5-{ }^{3} \mathrm{H}\right]-$ glucose, [U- $\left.{ }^{14} \mathrm{C}\right]-$ glucose, and anti-mouse IgG HRPconjugated secondary antibody were obtained from GE Healthcare (Buckinghamshire, UK). Acetyl-CoA was obtained from Wako (Osaka, Japan). Luciferin-luciferase was obtained from Promega. All other reagents were obtained from Sigma Chemicals.

\section{Animals}

Male Wistar rats were obtained from Shimizu Co. (Kyoto, Japan). The animals were fed standard laboratory chow ad libitum and allowed free access to water in an airconditioned room with a $12 \mathrm{~h}$ light: $12 \mathrm{~h}$ darkness cycle until the experiments. All experiments were carried out with rats aged 8-11 weeks. The animals were maintained and used in accordance with the Guidelines for Animal Experiments of Kyoto University.

\section{Islet isolation and culture}

Islets of Langerhans were isolated from Wistar rats by collagenase digestion as previously described (Fujimoto et al. 1998). Isolated islets were cultured for $24 \mathrm{~h}$ in RPMI 1640 medium containing $10 \% \mathrm{FCS}, 100 \mathrm{U} / \mathrm{ml}$ penicillin, $100 \mu \mathrm{g} / \mathrm{ml}$ streptomycin, and $5.5 \mathrm{mM}$ glucose with or without rapamycin, at $37^{\circ} \mathrm{C}$ in humidified air containing $5 \% \mathrm{CO}_{2}$.

\section{Measurement of insulin release from isolated rat pancreatic islets, insulin content, and DNA content}

Insulin release from intact islets was monitored using batch incubation as previously described (Fujimoto et al. 1998) using Krebs-Ringer bicarbonate buffer (KRBB) supplemented with $0 \cdot 2 \%$ BSA (fraction $\mathrm{V}$ ) and $10 \mathrm{mM}$ HEPES adjusted to $\mathrm{pH} 7 \cdot 4$ (KRBB medium). After cultured islets were preincubated at $37^{\circ} \mathrm{C}$ for $30 \mathrm{~min}$ in $\mathrm{KRBB}$ medium supplemented with $2.8 \mathrm{mM}$ glucose, groups of five islets were batch incubated for $30 \mathrm{~min}$ in $0.7 \mathrm{ml} \mathrm{KRBB}$ medium containing 2.8 and $16.7 \mathrm{mM}$ glucose with or without $100 \mu \mathrm{M} \alpha$-tocopherol plus $200 \mu \mathrm{M}$ ascorbate, or containing $2 \cdot 8$ and $16.7 \mathrm{mM} \boldsymbol{\alpha}$-ketoisocaproate (KIC). Before addition to KRBB medium, $\boldsymbol{\alpha}$-tocopherol was dissolved in ethanol at 1000-fold concentration. The same amount of ethanol was added to the control solution. At the end of the incubation period, the islets were pelleted by centrifugation, and aliquots of the buffer were sampled to determine the amount of immunoreactive insulin by RIA. After an aliquot of incubation medium for insulin release assay was taken, the islets remaining were lysed to determine insulin and DNA contents as previously described (Fujimoto et al. 2000).

\section{Measurement of ATP content}

ATP contents were determined as previously described (Kominato et al. 2008). Briefly, after groups of cultured islets were preincubated at $2.8 \mathrm{mM}$ glucose for $30 \mathrm{~min}$, groups of ten islets were incubated in tubes containing $0.5 \mathrm{ml} \mathrm{KRBB}$ medium supplemented with $2 \cdot 8$ or $16 \cdot 7 \mathrm{mM}$ glucose with or without $100 \mu \mathrm{M} \boldsymbol{\alpha}$-tocopherol plus $200 \mu \mathrm{M}$ ascorbate at $37^{\circ} \mathrm{C}$ for $30 \mathrm{~min}$. Incubation was stopped by the addition of $0.1 \mathrm{ml}$ of $2 \mathrm{M} \mathrm{HClO}_{4}$. The contents of tubes were immediately mixed with vortex and sonicated in ice-cold water. The tubes were then centrifuged, and a fraction $(0 \cdot 4 \mathrm{ml})$ of the supernatant was mixed with $0.1 \mathrm{ml}$ of $2 \mathrm{M}$ HEPES and $0 \cdot 1 \mathrm{ml}$ of $1 \mathrm{M} \mathrm{Na}_{2} \mathrm{CO}_{3}$. The ATP concentration was measured by adding $0 \cdot 2 \mathrm{ml}$ luciferin-luciferase solution to a fraction sample $(0 \cdot 1 \mathrm{ml})$ in a bioluminometer (Luminometer Model 20e, Turner Designs, Sunnyvale, CA, USA). To draw a standard curve, blanks and ATP standards were run through the entire procedure including the extraction steps.

\section{Measurement of glucose utilization and oxidation}

Glucose utilization and oxidation were measured using the previously described method (Nabe et al. 2006). Briefly, cultured islets were preincubated in KRBB medium with $2 \cdot 8 \mathrm{mM}$ glucose at $37^{\circ} \mathrm{C}$ for $30 \mathrm{~min}$. For glucose utilization measurements, tubes containing 25 islets in $150 \mu \mathrm{KRBB}$ medium containing 2.8 or $16.7 \mathrm{mM}$ glucose and $1.5 \mu \mathrm{Ci}$ $\left[5-{ }^{3} \mathrm{H}\right]$ glucose were placed into glass vials containing $0 \cdot 5 \mathrm{ml}$ water. The capped vials were incubated at $37^{\circ} \mathrm{C}$ for $90 \mathrm{~min}$. After incubation was stopped by adding $50 \mu \mathrm{l}$ of $1 \mathrm{M} \mathrm{HCl}$ into the incubation medium of the tubes without opening the caps, the capped vials were incubated overnight at $34^{\circ} \mathrm{C}$ to allow ${ }^{3} \mathrm{H}_{2} \mathrm{O}$ in the tubes to equilibrate with the water in the vial. Each tube was removed, and the disintegrations per minute of ${ }^{3} \mathrm{H}_{2} \mathrm{O}$ in the water were counted. For oxidation measurements, procedures were the same as those for utilization measurements, except for the use of $\left[\mathrm{U}_{-}{ }^{14} \mathrm{C}\right]$ glucose $(0.5 \mu \mathrm{Ci} /$ tube $)$ in place of $\left[5^{3} \mathrm{H}\right]$ glucose and the use of $0.5 \mathrm{ml}$ hydroxide of hyamine $10-\mathrm{X}$ (Packard, Meriden, CT, USA) in place of $0.5 \mathrm{ml}$ water.

www.endocrinology-journals.org 


\section{Measurement of glucokinase activity}

Glucokinase activity was measured by a fluorometric assay as previously described (Radu et al. 2005). Briefly, after cultured islets were preincubated with $\mathrm{KRBB}$ medium with $2 \cdot 8 \mathrm{mM}$ glucose, 100 islets were homogenized and the supernatants (islet extracts) were obtained from the homogenates by centrifugation. The glucose phosphorylation rate was estimated as the increase in $\mathrm{NADH}$ through the following reaction: glucose-6-phosphate $+\mathrm{NAD}^{+} \rightarrow 6$-phosphoglucono- $\delta$-lactone $+\mathrm{NADH}$ by $\mathrm{NAD}^{+}{ }^{+}$-dependent glucose- $6-$ phosphate dehydrogenase (G6PDH). The enzyme reaction was performed using islet extracts in a solution containing $\mathrm{NAD}^{+}$and G6PDH supplemented with two concentrations (50 and $0.5 \mathrm{mM}$ ) of glucose at $37^{\circ} \mathrm{C}$ for $1 \mathrm{~h}$. NADH concentration was measured by fluorometry (Shimazu RF-5000, Kyoto, Japan).Glucokinase activity was determined by subtracting hexokinase activity measured at $0.5 \mathrm{mM}$ glucose from the activity measured at $50 \mathrm{mM}$ glucose.

\section{Measurement of mitochondrial ATP production}

Measurement of ATP production from mitochondrial fraction was performed as previously described (Takehiro et al. 2005). Briefly, to measure ATP production by oxidative phosphorylation, the reaction was started by adding mitochondrial suspension to prewarmed solution $\left(37^{\circ} \mathrm{C}\right)$ supplemented with the mitochondrial substrates, $50 \mu \mathrm{M}$ ADP, and $1 \mu \mathrm{M}$ diadenosine pentaphosphate (DAPP). DAPP is a specific inhibitor of adenylate kinase used to measure ATP production by oxidative phosphorylation exclusively. To normalize the mass of the intact mitochondria obtained, ATP production by adenylate kinase, one of the mitochondrial intermembrane kinases, was measured in the presence of ADP but without mitochondrial substrates or DAPP in parallel incubations. After reaction was stopped, the ATP concentration in the solutions was measured by adding luciferin-luciferase solution with a bioluminometer. ATP production was determined as the ratio of ATP production by oxidative phosphorylation to that by adenylate kinase.

\section{Western blotting of mitochondrial respiratory chain complexes}

After washing with ice-cold PBS, the cultured islets were

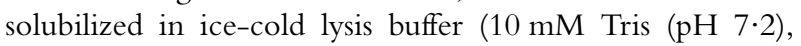
$100 \mathrm{mM} \mathrm{NaCl}, 1 \mathrm{mM}$ EDTA, 1\% Nonidet P-40, and 0.5\% sodium deoxycholate) containing protease inhibitor cocktail (Complete; Roche) with sonication ( $5 \mathrm{~s}$ pulse, five times). Protein content of the supernatant was measured and adjusted by Bradford method. The supernatant was dissolved in the same amount of SDS-PAGE sample buffer containing $100 \mathrm{mM}$ Tris- $\mathrm{HCl} \quad(\mathrm{pH} \quad 6 \cdot 80), \quad 4 \% \quad$ SDS, $12 \%$ 2-mercaptoethanol, 20\% glycerol, and 1\% bromophenol blue and boiled for $5 \mathrm{~min}$ at $95^{\circ} \mathrm{C}$. The samples were subjected to electrophoresis on $12 \%$ SDS-polyacrylamide gels and transferred onto nitrocellulose membrane (Schleicher \&
Schuell, Keene, NH, USA). After blocking with TBS containing $0 \cdot 1 \%$ Tween 20 and $5 \%$ skimmed milk (blocking buffer) for $1 \mathrm{~h}$ at $4{ }^{\circ} \mathrm{C}$, blotted membranes were incubated overnight at $4{ }^{\circ} \mathrm{C}$ with mouse monoclonal anti-complex I (39 kDa subunit), anti-complex III (core II), anti-complex IV (subunit I), or anti-complex V (subunit $\alpha$ ) of mitochondrial respiratory chain antibody at 1:1000 dilution in blocking buffer, and subsequently with anti-mouse $\operatorname{IgG}$ HRP-conjugated secondary antibody diluted 1:5000 at room temperature for $1 \mathrm{~h}$ prior to detection using ECL (GE Healthcare). In the same membrane, the process was repeated for $\beta$-actin at 1:5000 dilution of the antibody. Band intensities were quantified with Multi Gauge software (Fujifilm, Tokyo, Japan).

\section{Measurement of activities of enzymes in Krebs cycle}

Mitochondrial fraction obtained as described above was sonicated in ice-cold solution containing (mM) $180 \mathrm{KCl}$, 5 morpholinepropanesulfonic acid, and 2 EDTA adjusted to $\mathrm{pH} 7 \cdot 40$ and then diluted to each reaction mixture. Enzyme activities including $\mathrm{NAD}^{+}$-linked isocitrate dehydrogenase (NAD-ICDH), aconitase, $\boldsymbol{\alpha}$-ketoglutarate dehydrogenase $(\mathrm{KGDH})$, and malate dehydrogenase $(\mathrm{MDH})$ were measured as previously described (Nulton-Persson \& Szweda 2001). NAD-ICDH activities were measured as the rate of $\mathrm{NAD}^{+}$ reduction in solution A containing $(\mathrm{mM}) 25 \mathrm{KH}_{2} \mathrm{PO}_{4}, 0 \cdot 5$ EDTA, and $0 \cdot 01 \%$ Triton $\mathrm{X}-100$ adjusted to $\mathrm{pH} 7 \cdot 25$ supplemented with $2.5 \mathrm{mM}$ isocitrate, $40 \mu \mathrm{M}$ rotenone, $5 \mathrm{mM} \mathrm{MgCl}_{2}$, and $1 \mathrm{mM} \mathrm{NAD}^{+}$. Aconitase activities were measured as the rate of $\mathrm{NADP}^{+}$reduction in solution A with $5 \mathrm{mM}$ citrate, $0.6 \mathrm{mM} \mathrm{MgCl}_{2}, 1.0 \mathrm{U} / \mathrm{ml} \mathrm{NADP-ICDH}$, and $0.2 \mathrm{mM} \mathrm{NADP}^{+}$. KGDH activities were measured as the rate of $\mathrm{NAD}^{+}$reduction in solution A with $2.5 \mathrm{mM}$ $\alpha$-ketoglutarate, $40 \mu \mathrm{M}$ rotenone, $5.0 \mathrm{mM} \mathrm{MgCl}_{2}, 1 \mathrm{mM}$ $\mathrm{NAD}^{+}, 0 \cdot 1 \mathrm{mM} \mathrm{CoA}$, and $0 \cdot 2 \mathrm{mM}$ thymine pyrophosphate (TPP). MDH activities were measured as the rate of $\mathrm{NAD}^{+}$ reduction in solution A with $2.5 \mathrm{mM}$ malate, $40 \mu \mathrm{M}$ rotenone, $5 \mathrm{mM} \mathrm{MgCl} 2,10 \mathrm{mM} \mathrm{NAD}{ }^{+}, 0 \cdot 3 \mathrm{mM}$ acetyl$\mathrm{CoA}$, and $1 \mathrm{U} / \mathrm{ml}$ citrate synthase. Enzyme activities of pyruvate dehydrogenase (PDH) were measured as total PDH complex activity (Schwab et al. 2005) as the rate of $p$-iodonitrotetrazolium violet (INT) reduction in a reaction mixture containing $5 \mathrm{mM}$ L-carnitine, $1.0 \mathrm{mM} \mathrm{MgCl}_{2}$, $2.5 \mathrm{mM} \mathrm{NAD}^{+}, 0.1 \mathrm{mM}$ CoA, $5 \mathrm{mM}$ pyruvate, $0.2 \mathrm{mM}$ TPP, $0.1 \%$ Triton X-100, $1 \mathrm{~g} / 1 \mathrm{BSA}, 0.6 \mathrm{mM}$ INT, and $6.5 \mathrm{mM}$ phenazine methosulfate. All enzyme assays were performed at $25^{\circ} \mathrm{C}$.

\section{Statistical analysis}

The data are expressed as the mean \pm s.E.M. Statistical significance was calculated by unpaired Student's $t$-test. $P<0.05$ was considered significant. 


\section{Results}

Effect of chronic exposure to rapamycin on glucose-induced insulin release, insulin content, and DNA content in islets

Chronic (24 h) exposure to rapamycin (10, 30, and $100 \mathrm{nM})$ concentration dependently suppressed $16 \cdot 7 \mathrm{mM}$ glucoseinduced insulin release $(1.94 \pm 0.09,10 \mathrm{nM} ; 1.65 \pm 0.06$, $30 \mathrm{nM} ; 1 \cdot 50 \pm 0 \cdot 06,100 \mathrm{nM}$ rapamycin versus $2 \cdot 35$ $\pm 0 \cdot 11 \mathrm{ng} /$ islet per $30 \mathrm{~min}$, control, $n=30, P<0 \cdot 01$ respectively) but did not affect basal insulin release in the presence of $2.8 \mathrm{mM}$ glucose (Fig. 1A). Insulin secretion divided by insulin content also demonstrates that rapamycin suppresses glucose-induced insulin secretion (Fig. 1A). Insulin and DNA contents were not affected by 24-h exposure to 10, 30, and $100 \mathrm{nM}$ rapamycin (Table 1), indicating that these concentrations of rapamycin do not reduce islet $\beta$-cell mass. Reactive oxygen species (ROS) scavengers did not affect
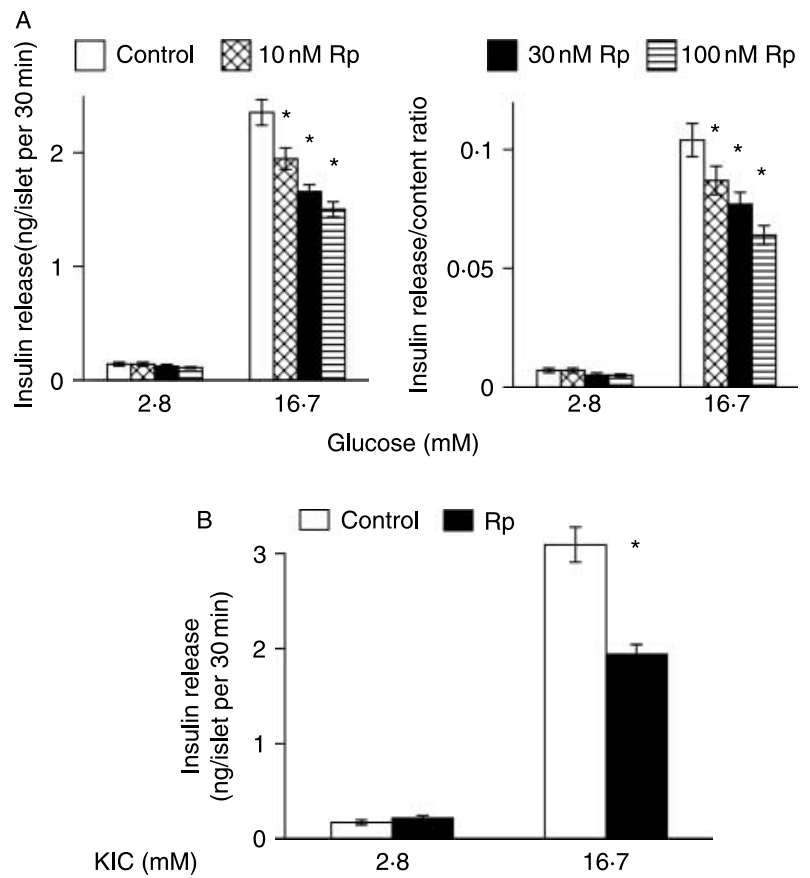

Figure 1 Effects of chronic exposure to rapamycin $(\mathrm{Rp})$ on fuel secretagogue-induced insulin release from islets. (A) High $(16.7 \mathrm{mM})$ glucose-induced and basal insulin release in control and Rp-treated islets. Islets were cultured with 10, 30, and $100 \mathrm{nM} \mathrm{Rp}$ or without Rp for $24 \mathrm{~h}$. After cultured islets were preincubated with $2 \cdot 8 \mathrm{mM}$ glucose for $30 \mathrm{~min}$, they were incubated with $2 \cdot 8$ and $16.7 \mathrm{mM}$ glucose. Insulin secretions are presented as insulin secretion for $30 \mathrm{~min} /$ islet (right) and as the ratio of insulin secretion for $30 \mathrm{~min}$ to insulin content (left). Values represent mean \pm s.E.M. of 30 determinations. $* P<0 \cdot 01$ versus corresponding control. (B) High $\mathrm{KIC}(16.7 \mathrm{mM})$-induced and basal insulin release in control and Rp-treated islets. Islets were cultured with or without $30 \mathrm{nM} \mathrm{Rp}$ for $24 \mathrm{~h}$. After cultured islets were preincubated with $2 \cdot 8 \mathrm{mM}$ glucose for $30 \mathrm{~min}$, they were incubated with $2 \cdot 8$ and $16 \cdot 7 \mathrm{mM} \mathrm{KIC}$. Values represent mean \pm S.E.M. of 18 determinations. ${ }^{*} P<0 \cdot 01$ versus corresponding control.
Table 1 Effect of chronic exposure to rapamycin on insulin content and DNA content. At the end of experiments indicated in Fig. 1A, insulin content and DNA content in islets were determined. Values represent mean \pm s.E.M. of 60 determinations

\begin{tabular}{lll} 
& $\begin{array}{c}\text { Insulin content } \\
\text { (ng/islet) }\end{array}$ & $\begin{array}{c}\text { DNA content } \\
\text { (ng/islet) }\end{array}$ \\
\cline { 2 - 2 } $\begin{array}{l}\text { Experimental condition } \\
\quad \text { during culture }\end{array}$ & & \\
$\begin{array}{l}\text { Control } \\
10 \mathrm{nM} \text { rapamycin }\end{array}$ & $24 \cdot 7 \pm 1 \cdot 0$ & \\
$30 \mathrm{nM}$ rapamycin & $24 \cdot 1 \pm 1 \cdot 0$ & \\
$100 \mathrm{nM}$ rapamycin & $24 \cdot 5 \pm 1 \cdot 1$ & \\
& $23 \cdot 7 \pm 0 \cdot 8$ & \\
\end{tabular}

suppressed glucose-induced insulin secretion by rapamycin $(1 \cdot 60 \pm 0 \cdot 10,30 \mathrm{nM}$ rapamycin versus $1 \cdot 69 \pm 0 \cdot 10 \mathrm{ng} /$ islet per $30 \mathrm{~min}, 30 \mathrm{nM}$ rapamycin with $\boldsymbol{\alpha}$-tocopherol plus ascorbate, $n=10$, not significant).

Effect of chronic exposure to rapamycin on KIC-induced insulin release

To characterize metabolic fuel-induced insulin release independent of glycolysis, KIC-induced insulin release from rapamycin-treated islets was examined. Chronic exposure to $30 \mathrm{nM}$ rapamycin decreased high KIC-induced insulin release $(1.93 \pm 0 \cdot 10$, rapamycin versus $3 \cdot 09 \pm 0 \cdot 18 \mathrm{ng}$ /islet per $30 \mathrm{~min}$, control, $n=18, P<0 \cdot 01$; Fig. $1 \mathrm{~B})$.

\section{Effect of rapamycin on $A T P$ content}

ATP content was greater in control islets incubated with $16.7 \mathrm{mM}$ glucose than in control islets incubated with $2.8 \mathrm{mM}$ glucose $(11.97 \pm 0.35,2.8 \mathrm{mM}$ glucose versus $16 \cdot 04 \pm 0 \cdot 46 \mathrm{pmol} /$ islet, $16 \cdot 7 \mathrm{mM}$ glucose, $n=30, P<0 \cdot 01$; Fig. 2). ATP content in the presence of $16.7 \mathrm{mM}$ glucose

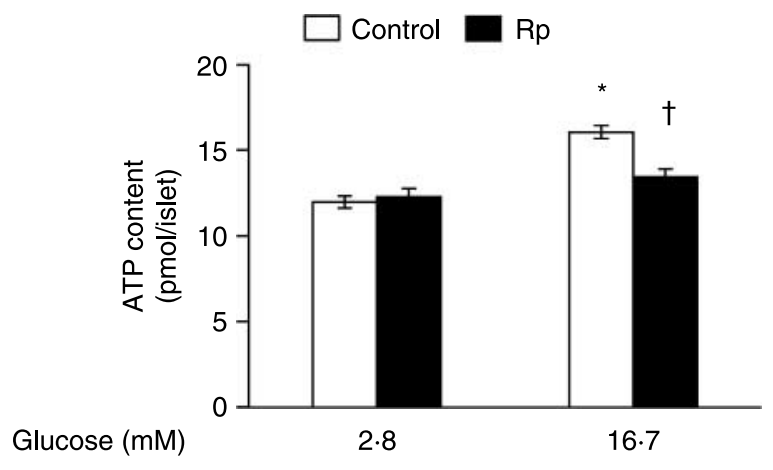

Figure 2 Effects of chronic exposure to rapamycin (Rp) on ATP contents in islets. Islets were cultured with or without $30 \mathrm{nM} \mathrm{Rp}$ for $24 \mathrm{~h}$. After cultured islets were preincubated with $2 \cdot 8 \mathrm{mM}$ glucose for $30 \mathrm{~min}$, and then incubated with $2 \cdot 8$ and $16.7 \mathrm{mM}$ glucose for $30 \mathrm{~min}$, ATP contents were determined. Values represent mean \pm S.E.M. of 30 determinations. ${ }^{*} P<0 \cdot 01$ versus control with $2.8 \mathrm{mM}$ glucose. ${ }^{\dagger} P<0 \cdot 01$ versus control with $16 \cdot 7 \mathrm{mM}$ glucose. 
was significantly reduced in rapamycin-treated islets $(13 \cdot 42$ $\pm 0.47 \mathrm{pmol} /$ islet, $16.7 \mathrm{mM}$ glucose, rapamycin versus $16.7 \mathrm{mM}$ glucose, control, $n=30, P<0.01)$, but that in the presence of $2 \cdot 8 \mathrm{mM}$ glucose was not affected by rapamycin (Fig. 2). ROS scavengers did not affect the suppressed ATP content in the presence of high glucose by rapamycin $(13 \cdot 27$ $\pm 0.92,30 \mathrm{nM}$ rapamycin versus $14.58 \pm 0.82 \mathrm{pmol} /$ islet, $30 \mathrm{nM}$ rapamycin with $\boldsymbol{\alpha}$-tocopherol plus ascorbate, $n=10$, not significant).

Effects of rapamycin on glucose utilization and glucose oxidation

Glucose utilization was greater in islets incubated with $16.7 \mathrm{mM}$ glucose than that in islets incubated with $2.8 \mathrm{mM}$ glucose in both control $(33 \cdot 0 \pm 1 \cdot 8,2 \cdot 8 \mathrm{mM}$ glucose versus $98 \cdot 4 \pm 5 \cdot 0 \mathrm{pmol} /$ islet per $90 \mathrm{~min}, 16.7 \mathrm{mM}$ glucose, $n=15$, $P<0 \cdot 01)$ and rapamycin-treated islets $(28 \cdot 1 \pm 1 \cdot 7,2.8 \mathrm{mM}$ glucose versus $75 \cdot 1 \pm 2.6 \mathrm{pmol} /$ islet per $90 \mathrm{~min}, 16.7 \mathrm{mM}$ glucose, $n=15, P<0 \cdot 01)$. Glucose utilization in the presence of $16.7 \mathrm{mM}$ glucose was significantly reduced in rapamycintreated islets $(P<0 \cdot 01)$, but that in the presence of $2.8 \mathrm{mM}$ glucose was not affected by rapamycin (Fig. 3A).

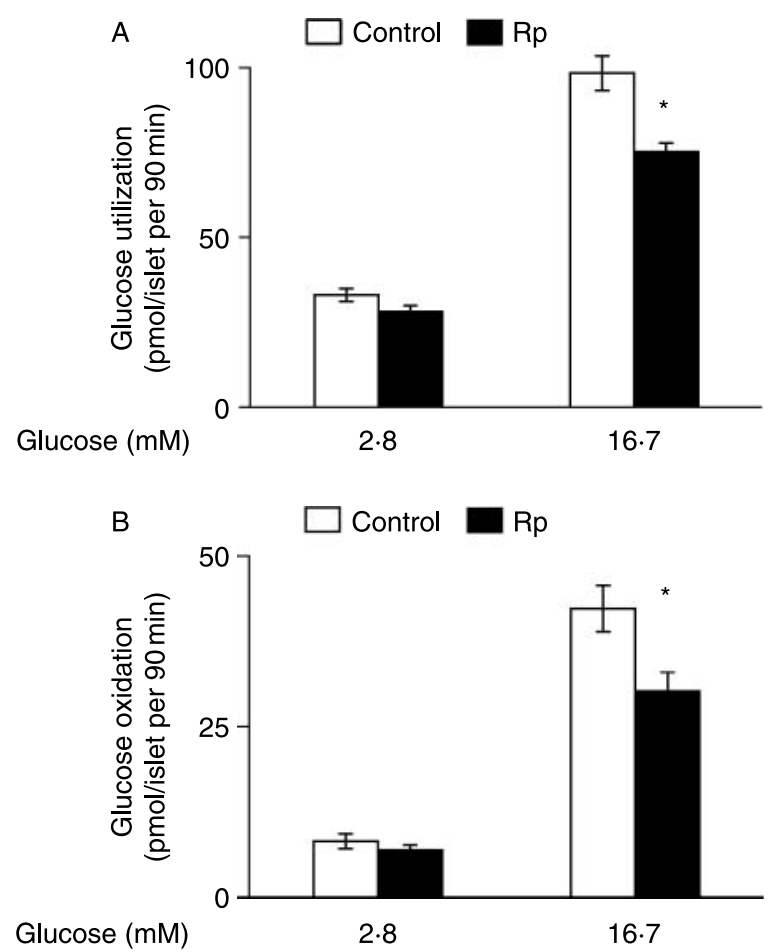

Figure 3 Effects of chronic exposure to rapamycin (Rp) on glucose utilization and oxidation in islets. Islets were cultured with or without $30 \mathrm{nM} \mathrm{Rp}$ for $24 \mathrm{~h}$. After cultured islets were preincubated with $2.8 \mathrm{mM}$ glucose for $30 \mathrm{~min}$, they were incubated with $2 \cdot 8$ and $16.7 \mathrm{mM}$ glucose for $90 \mathrm{~min}$. (A) Glucose utilization. Values represent mean \pm s.E.M. of 15 determinations. ${ }^{*} P<0 \cdot 01$ versus corresponding control. (B) Glucose oxidation. Values represent mean \pm S.E.M. of nine determinations. ${ }^{*} P<0 \cdot 01$ versus corresponding control.
Glucose oxidation was greater in islets incubated with $16.7 \mathrm{mM}$ glucose than that in islets incubated with $2.8 \mathrm{mM}$ glucose in both control $(8 \cdot 1 \pm 1 \cdot 1,2 \cdot 8 \mathrm{mM}$ glucose versus $42 \cdot 2 \pm 3 \cdot 3 \mathrm{pmol} /$ islet per $90 \mathrm{~min}, 16 \cdot 7 \mathrm{mM}$ glucose, $n=9$, $P<0 \cdot 01)$ and rapamycin-treated islets $(6 \cdot 8 \pm 0 \cdot 7,2.8 \mathrm{mM}$ glucose versus $30 \cdot 1 \pm 2.7 \mathrm{pmol} /$ islet per $90 \mathrm{~min}, 16.7 \mathrm{mM}$ glucose, $n=9, P<0 \cdot 01)$. Glucose oxidation in the presence of $16.7 \mathrm{mM}$ glucose was significantly reduced in rapamycintreated islets $(P<0 \cdot 01)$, but that in the presence of $2.8 \mathrm{mM}$ glucose was not affected by rapamycin (Fig. 3B). Glucose oxidation in the presence of $16.7 \mathrm{mM}$ glucose declined $77 \%$ by $100 \mathrm{nM}$ antimycin $\mathrm{A}$, which is comparable with the reduction by rapamycin treatment. In the same condition, glucose utilization with high glucose also declined $78 \%$ by antimycin A (Table 2).

\section{Effect of rapamycin on glucokinase activity}

Glucokinase activity was not affected by rapamycin treatment $(87 \cdot 4 \pm 10 \cdot 4$, rapamycin versus $75 \cdot 4 \pm 14 \cdot 8 \mathrm{pmol} /$ islet per $60 \min$, control, $n=3$, not significant).

Effect of rapamycin on expression of mitochondrial respiratory chain complexes

Immunoblotting using lysates of whole islets revealed that rapamycin did not affect expression of complex I, III, IV, and $\mathrm{V}$ of the mitochondrial respiratory chain proteins (Fig. 4).

\section{Effect of rapamycin on ATP production by mitochondria from} islets

ATP production by mitochondria from control and rapamycin-cultured islets in the presence of various substrates and inhibitors is shown in Table 3. Antimycin A, a complex III inhibitor in the respiratory chain, inhibited ATP production dramatically in the presence of succinate in mitochondria from both control and rapamycin-cultured islets. Mitochondrial ATP production of rapamycin-cultured islets was similar to that of control islets in the presence of

Table 2 Effect of antimycin A on glucose oxidation and glucose utilization. Islets were cultured without rapamycin for $24 \mathrm{~h}$. After cultured islets were preincubated with $2.8 \mathrm{mM}$ glucose for $30 \mathrm{~min}$, they were incubated with $2 \cdot 8$ and $16 \cdot 7 \mathrm{mM}$ glucose for 90 min with or without $100 \mathrm{nM}$ antimycin A. Values represent mean \pm s.E.M. of nine (glucose oxidation) and five (glucose utilization) determinations

\begin{tabular}{crcc} 
& \multicolumn{1}{c}{ Control } & & $\mathbf{1 0 0} \mathbf{~ n M}$ antimycin A \\
Glucose oxidation & & \\
$2 \cdot 8 \mathrm{mM}$ glucose & $9 \cdot 8 \pm 0 \cdot 5$ & & $9 \cdot 8 \pm 0 \cdot 7$ \\
$16 \cdot 7 \mathrm{mM}$ glucose & $42 \cdot 1 \pm 1 \cdot 8$ & & $32 \cdot 8 \pm 1 \cdot 8^{*}$ \\
Glucose utilization & & \\
$2 \cdot 8 \mathrm{mM}$ glucose & $32 \cdot 9 \pm 3 \cdot 3$ & & $31 \cdot 1 \pm 2 \cdot 4$ \\
$16 \cdot 7 \mathrm{mM}$ glucose & $97 \cdot 9 \pm 5 \cdot 6$ & $76 \cdot 7 \pm 6 \cdot 5^{+}$
\end{tabular}

$* P<0.01$ versus control without antimycin $\mathrm{A} .{ }^{+} P<0.05$ versus control without antimycin A. 


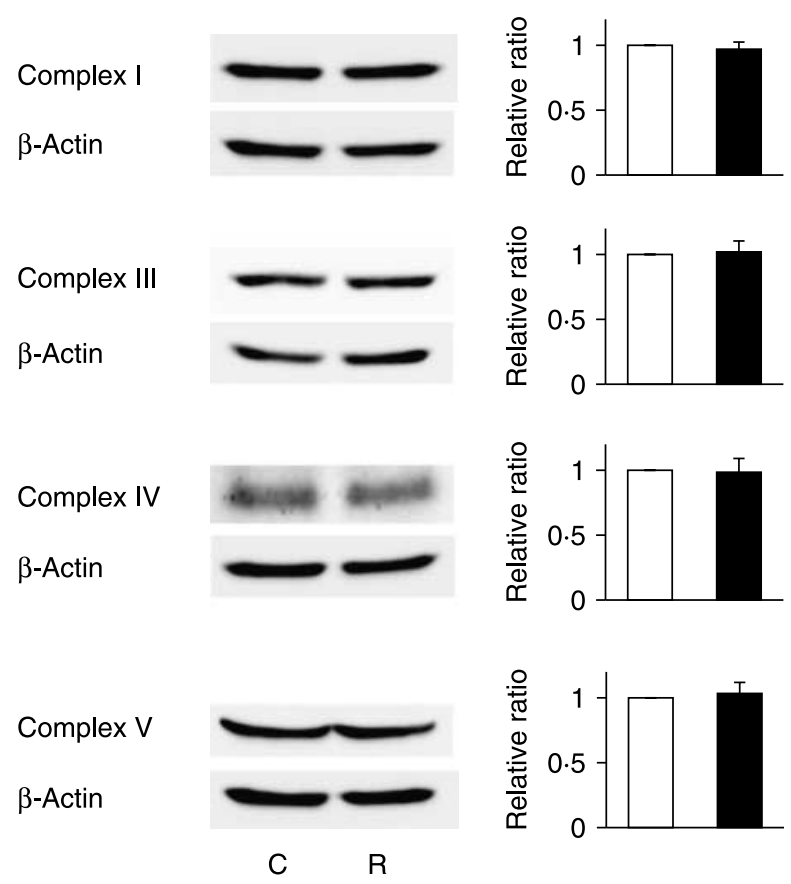

Figure 4 Immunoblots of complex I, III, VI, and V of mitochondrial respiratory chain proteins using lysates of whole-rat pancreatic islets. Islets were cultured with or without $30 \mathrm{nM}$ rapamycin for 24 h. C, control; R, rapamycin. Quantification data from several independent experiments (I, n=4; III, n=4; VI, $n=3 ; \mathrm{V}, n=4)$ are also indicated. Open bar, control; closed bar, rapamycin. Data are expressed relative to control (without rapamycin) values corrected by $\beta$-actin level to eliminate influence of subtle difference in amount of loaded protein (means \pm s.E.M).

succinate plus rotenone, TMPD plus ascorbate, and glycerol3-phosphate. ATP production by mitochondria from rapamycin-cultured islets in the presence of pyruvate plus malate was decreased compared with that from control islets.

$\alpha$-Keto- $\beta$-methyl- $n$-valeric acid (KMV), a specific competitive inhibitor of KGDH, dose dependently suppressed mitochondrial ATP production in the presence of malate and pyruvate (Fig. 5).

\section{Effect of rapamycin on activities of mitochondrial enzymes}

Enzyme activities in the Krebs cycle including PDH, NAD$\mathrm{ICDH}$, aconitase, and $\mathrm{MDH}$ were not affected, but KGDH activity was reduced by rapamycin treatment (Table 4).

\section{Discussion}

In the present study, we show that rapamycin suppresses high glucose-induced insulin secretion from pancreatic islets by reducing mitochondrial ATP production through suppression of carbohydrate metabolism in the Krebs cycle, together with reduced KGDH activity. Thus, dysfunction in mitochondrial ATP production may be derived not from alteration in protein expression and dysfunction of the respiratory chain but from decreased KGDH activity that limits the velocity of carbohydrate metabolism in the Krebs cycle.

Rapamycin significantly decreased glucose-induced insulin release after 1 to several days exposure, as found in previous studies using rat islets (Bell et al. 2003) and mice islets (Zhang et al. 2006). In the present study, exposure to $30 \mathrm{nM}$ rapamycin for $24 \mathrm{~h}$ reduced glucose-induced insulin release without affecting insulin and DNA content, which indicates that reduced insulin release by rapamycin is not necessarily derived from reduced $\beta$-cell mass, while rapamycin above $10 \mathrm{nM}$ was found to increase apoptosis in MIN-6 cells in a previous study (Bell et al. 2003). To investigate the mechanism of reduced insulin release by rapamycin independent of reduced insulin and DNA content, we used $30 \mathrm{nM}$ rapamycin-treated islets. The recommended trough concentrations of rapamycin in blood are $5-15 \mathrm{ng} / \mathrm{ml}$ (or $5.5-15.9 \mathrm{nM}$ ) in islet transplantation (Shapiro et al. 2000) and renal transplantation (Teutonico et al. 2005). Accordingly, the concentration used in our experiments was two to six times clinically used trough concentrations.

In pancreatic $\beta$-cells, intracellular ATP originated mainly from mitochondria is one of the most important regulators of insulin secretion (Maechler \& Wollheim 2001). Glucose entry into the $\beta$-cells accelerates glycolysis and mitochondrial carbohydrate metabolism that increases ATP content and ATP/ADP ratio, which closes the ATP-sensitive $\mathrm{K}^{+}$channels ( $\mathrm{K}_{\text {ATP }}$ channel). The decrease in $\mathrm{K}^{+}$conductance depolarizes the membrane and opens the voltage-dependent $\mathrm{Ca}^{2+}$ channels (VDCCs). Increased $\mathrm{Ca}^{2+}$ influx through VDCCs increases the intracellular $\mathrm{Ca}^{2+}$ concentration to a level that triggers

Table 3 ATP production by mitochondria from control and rapamycin $(\mathrm{Rp})$-cultured islets. Islets were cultured with or without $30 \mathrm{nM} \mathrm{Rp}$ for $24 \mathrm{~h}$. Mitochondrial suspension was obtained from control and Rp-cultured islets. Mitochondrial ATP production is indicated as the ratio to ATP production from adenylate kinase, which was determined from the same sample in parallel incubation. Values represent mean \pm s.E.M. of five (A) and three (B) determinations

$\begin{array}{lll}\text { Experimental conditions } & \begin{array}{c}\text { Control } \\ \text { islets }\end{array} & \begin{array}{c}\text { Rp-cultured } \\ \text { islets }\end{array} \\ \text { A } & & \\ 1 \mathrm{mM} \text { succinate }+1 \mu \mathrm{M} \text { rotenone } & 6 \cdot 40 \pm 0 \cdot 32 & 6 \cdot 47 \pm 0 \cdot 44 \\ 1 \mathrm{mM} \text { pyruvate }+1 \mathrm{mM} \text { malate } & 3 \cdot 22 \pm 0 \cdot 10 & 2 \cdot 69 \pm 0 \cdot 11^{*} \\ 0 \cdot 5 \mathrm{mM} \text { TMPD }+2 \mathrm{mM} \text { ascorbate } & 8 \cdot 74 \pm 1 \cdot 44 & 8 \cdot 70 \pm 1 \cdot 34 \\ 1 \mathrm{mM} \text { glycerol-3-phosphate } & 0 \cdot 66 \pm 0 \cdot 13 & 0 \cdot 55 \pm 0 \cdot 08 \\ 1 \mathrm{mM} \text { succinate }+1 \mu \mathrm{M} \text { antimycin } \mathrm{A} & 0 \cdot 02 \pm 0 \cdot 00 & 0 \cdot 02 \pm 0 \cdot 00 \\ \mathrm{~B} & & \\ 1 \mathrm{mM} \text { succinate } & 7 \cdot 13 \pm 0 \cdot 12 \mathrm{ND} \\ 1 \mathrm{mM} \text { succinate }+1 \mu \mathrm{M} \text { rotenone } & 6 \cdot 39 \pm 0 \cdot 06 & \mathrm{ND} \\ 1 \mathrm{mM} \text { succinate }+1 \mu \mathrm{M} \text { antimycin } \mathrm{A} & 0 \cdot 02 \pm 0 \cdot 01 & \mathrm{ND} \\ 1 \mathrm{mM} \text { succinate }+1 \mu \mathrm{M} \text { rotenone }+1 & 0 \cdot 03 \pm 0 \cdot 00 & \mathrm{ND} \\ \mu \mathrm{M} \text { antimycin } \mathrm{A} & & \end{array}$

Mitochondrial ATP production

$\begin{array}{cc}\text { Control } & \text { Rp-cultured } \\ \text { islets } & \text { islets }\end{array}$

$* P<0 \cdot 05$ versus corresponding control cultured without Rp. TMPD, tetramethyl-p-phenyldiamine. ND, not determined. 


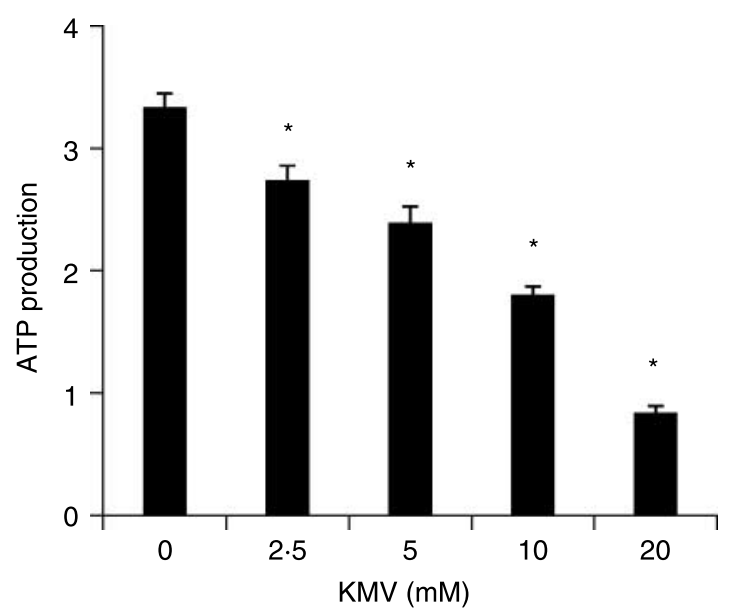

Figure 5 Effect of $\alpha$-keto- $\beta$-methyl- $n$-valeric acid (KMV) on mitochondrial ATP production. Islets were cultured for $24 \mathrm{~h}$. Mitochondrial suspension was obtained from cultured islets. Mitochondrial ATP production in the presence of $1 \mathrm{mM}$ pyruvate and $1 \mathrm{mM}$ malate with various concentrations of $\mathrm{KMV}$ is indicated as the ratio to ATP production from adenylate kinase, which was determined from the same sample in parallel incubation. Values represent mean \pm s.E.M. of six determinations. $* P<0 \cdot 01$ versus control without KMV.

exocytosis of the insulin granules. Moreover, ATP directly affects the exocytotic system and enhances insulin release in experiments using single $\beta$-cells (Rorsman 1997, Takahashi et al. 1999) and permeabilized islets (Fujimoto et al. 2002). Thus, a lower ATP level in the presence of high glucose plays a major role in the attenuation of insulin secretion from rapamycintreated islets in response to high glucose.

In pancreatic islets, KIC is oxidized, enhancing ATP production and triggering insulin release (Malaisse et al. 1981), and two distinct mechanisms of KIC-induced insulin release are proposed. In one, $\mathrm{KIC}$, which is converted to acetyl CoA via a branched chain $\boldsymbol{\alpha}$-keto acid dehydrogenase (BCKDH) -dependent pathway, enters into the Krebs cycle and is oxidized (Lenzen et al. 1982, 1985). In the other,

Table 4 Effect of rapamycin (Rp) on enzyme activities in the Krebs cycle. Islets were cultured with or without $30 \mathrm{nM} \mathrm{Rp}$ for $24 \mathrm{~h}$.

Enzyme activities were measured using homogenates of mitochondrial fraction obtained from control and Rp-cultured islets. Values represent mean \pm S.E.M. of five determinations

Enzyme activities (nmol/mg mitochondrial protein per $\mathrm{min}$ )

$\begin{array}{lcc}\text { PDH } & 10 \cdot 64 \pm 0 \cdot 38 & 10 \cdot 98 \pm 0 \cdot 38 \\ \text { Aconitase } & 10 \cdot 83 \pm 0 \cdot 78 & 9 \cdot 77 \pm 0 \cdot 78 \\ \text { NAD-ICDH } & 11 \cdot 50 \pm 0 \cdot 28 & 10 \cdot 99 \pm 0 \cdot 30 \\ \text { KGDH } & 13 \cdot 82 \pm 0 \cdot 84 & 10 \cdot 08 \pm 0 \cdot 82^{*} \\ \text { MDH } & 1116 \pm 37 & 1127 \pm 37\end{array}$

$* P<0.05$ versus corresponding control cultured without Rp. PDH, pyruvate dehydrogenase; NAD-ICDH, NAD ${ }^{+}$linked-isocitrate dehydrogenase; $\mathrm{KGDH}, \alpha$-ketoglutarate dehydrogenase; $\mathrm{MDH}$, malate dehydrogenase.
KIC together with endogenous glutamate is converted to $\boldsymbol{\alpha}$-ketoglutarate via glutamate-keto acid transaminase (GKAT), which enters into the Krebs cycle and is oxidized (Gao et al. 2003). Because both BCKDH and GKAT are mitochondrial enzymes, KIC might well be metabolized within mitochondria without affecting cytosolic glycolysis, which is compatible with the results showing that inhibition of glycolysis by glucokinase inhibitor and glyceraldehyde-3phosphate dehydrogenase inhibitor decreased glucoseinduced insulin release, but did not affect KIC-induced insulin release (Radu et al. 2005). Reduced KIC-induced insulin release by rapamycin suggests that the decreased glucose metabolism may be derived from reduced mitochondrial carbohydrate metabolism.

Because rapamycin reduced glucose utilization in the presence of high glucose, which reflects the velocity of glycolysis (Meglasson \& Matschinsky 1986), the activity of glucokinase, a rate-limiting enzyme in glycolysis (Matschinsky 1996), was examined. Since rapamycin treatment did not affect glucokinase activity in islets, the primary cause of reduced glucose oxidation by the treatment is not likely to be reduced the velocity of glycolysis. Indeed, in islets, glucose utilization is also reduced when glucose oxidation is decreased by respiratory chain inhibitors including site III inhibitor in our results and site VI inhibitor (Sener et al. 2007), suggesting that reduced glucose oxidation may decrease glucose utilization. Since glucokinase is a unique hexokinase, which lacks product inhibition (Matschinsky 2002), accumulation of glucose-6-phosphate by mitochondrial metabolic inhibition may not participate in glycolysis inhibition. Moreover, since $K_{\mathrm{m}}$ of glucokinase for ATP is about $0.5 \mathrm{mM}$, which is less than the estimated cytosolic ATP concentration with a basal level of glucose in $\beta$-cells (about $3 \mathrm{mM}$; Meglasson \& Matschinsky 1984), a decrease in the cytosolic ATP concentration by mitochondrial metabolic inhibition may have little effect on velocity of glycolysis.

Mitochondrial ATP production is driven by the $\mathrm{H}^{+}$ gradient across the mitochondrial membrane generated by transport of high-energy electrons in the respiratory chain. These electrons are derived from $\mathrm{NADH}$ and $\mathrm{FADH}_{2}$ derived from the Krebs cycle in the matrix and/or transferred from the cytosol by the shuttle system. To find the defective site in mitochondrial carbohydrate metabolism in rapamycincultured islets, mitochondrial ATP production was examined in the presence of various substrates and inhibitors. As ATP production in the presence of glycerol phosphate was not affected, reduced function of the glycerol phosphate shuttle, which is observed in diabetic islets (Östenson et al. 1993), may not participate in the reduction of ATP production by rapamycin treatment. In the presence of rotenone, a complex I inhibitor, and succinate, which renders electrons indirectly to complex I via the Krebs cycle and directly to complex II, electrons are rendered to the respiratory chain via $\mathrm{FADH}_{2}$ at complex II and not at complex I via NADH, which is derived from metabolism in the Krebs cycle. TMPD is an artificial 
electron donor that can transfer electrons to cytochrome $c$. TMPD reduced by ascorbate renders electrons to cytochrome $c$, which transfers electrons to complex IV. The fact that ATP production in the presence of succinate plus rotenone and in the presence of TMPD plus ascorbate is similar in the two groups of mitochondria indicates that the respiratory chain downstream of complex II is not affected by chronic exposure to rapamycin. Moreover, immunoblotting revealed that expressions of respiratory chain proteins including complex I, III, IV, and V were not affected by rapamycin treatment. Antibodies used in the present study were raised against $39 \mathrm{kDa}$ subunit in complex I, core II in complex III, subunit I in complex IV, and subunit $\alpha$ in complex V. In these subunits, subunit I in complex IV is derived from an mtDNA-encoded gene; the others are from nuclear genes (Hunte 2001, Richter \& Ludwig 2003, Scheffler 2008, Zickermann et al. 2009), indicating that rapamycin does not affect the expression of respiratory proteins derived from mtDNA or nuclear genes in islets. Considered together, these results do not support the notion that rapamycin reduces ATP production by reducing activity of the respiratory chain. Because the decrease in ATP production was found in the presence of substrates that are metabolizable in the Krebs cycle by rapamycin treatment, the reduction in ATP production may be attributable to reduced carbohydrate metabolism in the Krebs cycle.

Glucose oxidation reflects the velocity of carbohydrate metabolism in the Krebs cycle in which $\mathrm{CO}_{2}$ is released in the reaction mediated by dehydrogenases. To clarify the link between reduced mitochondrial ATP production in the presence of substrates metabolizable in the Krebs cycle and reduced glucose oxidation by rapamycin, recovery of insulin release and ATP content in the presence of high glucose by ROS scavengers and activity of enzymes in the Krebs cycle were examined. Ouabain-induced endogenous ROS suppresses mitochondrial metabolism in the Krebs cycle, subsequently reducing ATP production, and reduces glucose-induced insulin release and ATP levels in the presence of high glucose, which is recovered by the suppression of endogenous ROS production and by ROS scavenge (Kajikawa et al. 2002, Kominato et al. 2008). High glucose raises ROS level in $\beta$-cells (Bindokas et al. 2003, Sakai et al. 2003), which is also found in our previous study (Kominato et al. 2008). However, our previous study shows that ROS scavenging does not affect glucose-induced insulin secretion from control islets, but increases that from GK-diabetic islets. A more profound increase in high glucose-induced ROS was observed in diabetic islets compared with control islets. These results suggest that a physiological level of ROS increase by glucose does not impair stimulus-secretion coupling, while a pathophysiological increase in ROS impairs stimulus-secretion coupling. Administration of $\mathrm{H}_{2} \mathrm{O}_{2}$, the most abundant ROS, to mitochondria reduced the activity of Krebs cycle enzymes including aconitase, $\mathrm{KGDH}$, and succinate dehydrogenase (Tretter \& Adam-Vizi 2000, Nulton-Persson \& Szweda 2001). Because $\boldsymbol{\alpha}$-tocopherol is a lipid-soluble antioxidant, it is often used as membrane-permeable ROS scavenger. $\boldsymbol{\alpha}$-tocopherol reduces ROS production in various kinds of cells (Saito et al. 2003, Brookheart et al. 2009, Yang et al. 2009) including $\beta$-cells (Kajikawa et al. 2002). As ascorbate is water soluble, it is not necessarily membrane permeable. However, it is useful to prevent oxidization of $\boldsymbol{\alpha}$-tocopherol in the medium and to maintain the ROS-scavenging effect of $\alpha$-tocopherol. Because insulin release and ATP content in the presence of high glucose in rapamycin-treated islets were not increased by the addition of $\boldsymbol{\alpha}$-tocopherol plus ascorbate, overproduction of endogenous ROS seems not to participate in reduced mitochondrial carbohydrate metabolism due to rapamycin treatment.

Impaired metabolism-secretion coupling in $\beta$-cells due to reduced activity of enzymes in the Krebs cycle has been reported. Exposure to fatty acids for $48 \mathrm{~h}$ inhibits glucoseinduced insulin secretion from islets with decreased activity in PDH (Zhou \& Grill 1995). Interleukin-1 $\beta$-induced nitric oxide production leads to inhibition of glucose-induced insulin secretion together with reduced aconitase activity (Welsh et al. 1991). In the present study, activity of $\mathrm{KGDH}$ was decreased by rapamycin treatment. The reaction catalyzed by $\mathrm{KGDH}$ is one of the slowest steps in the Krebs cycle, and thus can be the rate-limiting step in islets (Ashcroft 1981) and in other tissues (Tretter \& Adam-Vizi 2000, Nulton-Persson \& Szweda 2001). Inhibition of KGDH alters mitochondrial function in N2a neuroblastoma cells (Huang et al. 2003). These findings suggest that decreased activity of $\mathrm{KGDH}$ might reduce mitochondrial ATP production and result in decreased glucose-induced insulin secretion from rapamycin-treated islets. To investigate this, suppression of mitochondrial ATP production by inhibition of KGDH was examined using KMV, a specific competitive inhibitor of KGDH (Huang et al. 2003). KMV dose dependently suppressed mitochondrial ATP production in the presence of malate and pyruvate. This dose dependency of KMV on mitochondrial ATP production is consistent with the dosedependent effect of KMV on KGDH activities previously described (Huang et al. 2003). These results indicate that reaction at $\mathrm{KGDH}$ may limit the velocity of carbohydrate metabolism in the Krebs cycle and thus mitochondrial ATP production, which is consistent with the result that $\mathrm{KGDH}$ limits the amount of NADH available for the respiratory chain (Tretter \& Adam-Vizi 2000). These results support the notion that a slight alteration in KGDH activity may affect mitochondrial ATP production.

While rapamycin shares with tacrolimus a similar molecular structure and binding ability to FK-binding protein 12 (FKBP12), the FKBP12-rapamycin complex has no effect on calcineurin, a phosphatase that is known to be inhibited by the FKBP12-tacrolimus complex (Saunders et al. 2001). This is consistent with our finding in the present study that rapamycin had no effect on glucokinase activity, but tacrolimus suppresses glucokinase activity in islets (Radu et al. 2005). MTOR has an FKBP12-rapamycin binding domain to which phosphatidic acid (PA) can also bind. 
MTOR expresses biological effects by forming two types of complexes, MTORC1 and MTORC2, which includes MTOR and PA commonly and Raptor and Rictor respectively. FKBP12-rapamycin is believed to inhibit MTOR signaling by preventing the interaction between MTOR and PA and thus forming MTOR complexes (Foster \& Toschi 2009). Since low concentrations of rapamycin $(0 \cdot 5-100 \mathrm{nM})$ target MTORC1 and higher concentrations of rapamycin $(0 \cdot 2-20 \mu \mathrm{M})$ target MTORC2 (Foster \& Toschi 2009), our result may be derived from inhibition of signaling mediated by MTORC1.

Recently, it has been revealed that MTOR is a nutrient sensor that balances energy metabolism by transcriptional control of mitochondrial oxidative function using peroxisome proliferator-activated receptor $\gamma$ coactivator- $1 \alpha$ in skeletal muscle cells (Cunningham et al. 2007). Further investigation of suppression of KGDH activity by rapamycin is required to clarify adaptation of mitochondrial oxidative function and insulin secretion according to nutrient supply.

\section{Declaration of interest}

The authors declare that there is no conflict of interest that would prejudice the impartiality of this scientific work.

\section{Funding}

This study was supported by Scientific Research Grants, a Grant for Leading Project for Biosimulation from the Ministry of Education, Culture, Sports, Science, and Technology of Japan, and a grant from CREST of Japan Science and Technology Cooperation.

\section{Acknowledgements}

The authors thank Mr T Yamaguchi and Ms C Kotake for their technical assistance.

\section{References}

Ashcroft SJH 1981 Metabolic control of insulin secretion. In The Islets of Langerhans: Biochemistry, Physiology, and Pathology, pp 117-148. Eds SJ Cooperstein \& D Watkins. New York: Academic Press.

Bell E, Cao X, Moibi JA, Greene SR, Young R, Trucco M, Gao Z, Matschinsky FM, Deng S, Markman JF et al. 2003 Rapamycin has a deleterious effect on MIN-6 cells and rat and human islets. Diabetes $\mathbf{5 2}$ 2731-2739.

Bindokas VP, Kuznetsov A, Sreenan S, Polonsky KS, Roe MW \& Philipson LH 2003 Visualizing superoxide production in normal and diabetic rat islets of Langerhans. Journal of Biological Chemistry 278 9796-9801.

Brookheart RT, Michel CI, Listenberger LL, Ory DS \& Schaffer JE 2009 The non-coding RNA gadd7 is a regulator of lipid-induced oxidative and endoplasmic reticulum stress. Journal of Biological Chemistry 284 7446-7454.

Cho HJ, Park J, Lee HW, Lee YS \& Kim JB 2004 Regulation of adipocyte differentiation and insulin action with rapamycin. Biochemical and Biophysical Research Communications 321 942-948.

Cunningham JT, Rodgers JT, Arlow DH, Vazquez F, Mootha VK \& Puigserver P 2007 mTOR controls mitochondrial oxidative function through a YY1-PGC-1 $\alpha$ transcriptional complex. Nature 450 736-740.
Foster DA \& Toschi A 2009 Targeting mTOR with rapamycin: one dose does not fit all. Cell Cycle 8 1026-1029.

Fraenkel M, Ketzinel-Gilad M, Ariav Y, Pappo O, Karaca M, Castel J, Berthault MF, Magnan C, Cerasi E, Kaiser N et al. 2008 mTOR inhibition by rapamycin prevents $\beta$-cell adaptation to hyperglycemia and exacerbates the metabolic state in type 2 diabetes. Diabetes 57 945-957.

Fujimoto S, Ishida H, Kato S, Okamoto Y, Tsuji K, Mizuno N, Ueda S, Mukai E \& Seino Y 1998 The novel insulinotropic mechanism of pimobendan: direct enhancement of the exocytotic process of insulin secretory granules by increased $\mathrm{Ca}^{2+}$ sensitivity in $\beta$-cells. Endocrinology 139 1133-1140.

Fujimoto S, Tsuura Y, Ishida H, Tsuji K, Mukai E, Kajikawa M, Hamamoto Y, Takeda T, Yamada Y \& Seino Y 2000 Augmentation of basal insulin release from rat islets by preexposure to a high concentration of glucose. American Journal of Physiology 279 E927-E940.

Fujimoto S, Mukai E, Hamamoto Y, Takeda T, Takehiro M, Yamada Y \& Seino Y 2002 Prior exposure to high glucose augments depolarizationinduced insulin release by mitigating the decline of ATP level in rat islets. Endocrinology 143 213-221.

Fujimoto S, Nabe K, Takehiro M, Shimodahira M, Kajikawa M, Takeda T, Mukai E, Inagaki N \& Seino Y 2007 Impaired metabolism-secretion coupling in pancreatic $\beta$-cells: role of determinants of mitochondrial ATP production. Diabetes Research and Clinical Practice 77 S2-S10.

Gao Z, Young RA, Li G, Najafi H, Buettger C, Sukumvanich SS, Wong RK, Wolf BA \& Matschinsky FM 2003 Distinguishing features of leucine and $\alpha$-ketoisocaproate sensing in pancreatic $\beta$-cells. Endocrinology 144 1949-1957.

Huang HM, Zhang H, Xu H \& Gibson GE 2003 Inhibition of the $\alpha$-ketoglutarate dehydrogenase complex alters mitochondrial function and cellular calcium regulation. Biochimica et Biophysica Acta 1637 119-126.

Hunte C 2001 Insights from the structure of the yeast cytochrome bc1 complex: crystallization of membrane proteins with antibody fragments. FEBS Letters 504 126-132.

Kajikawa M, Fujimoto S, Tsuura Y, Mukai E, Takeda T, Hamamoto Y, Takehiro M, Fujita J, Yamada Y \& Seino Y 2002 Ouabain suppresses glucose-induced mitochondrial ATP production and insulin release by generating reactive oxygen species in pancreatic islets. Diabetes $\mathbf{5 1}$ 2522-2529.

Kennedy ED, Maechler P \& Wollheim CB 1998 Effects of depletion of mitochondrial DNA in metabolism secretion coupling in INS-1 cells. Diabetes 47 374-380.

Kominato R, Fujimoto S, Mukai E, Nakamura Y, Nabe K, Shimodahira M, Nishi Y, Funakoshi S, Seino Y \& Inagaki N 2008 Src activation generates reactive oxygen species and impairs metabolism-secretion coupling in diabetic Goto-Kakizaki and ouabain-treated rat pancreatic islets. Diabetologia 51 1226-1235.

Lenzen S, Formanek H \& Panten U 1982 Signal function of metabolism of neutral amino acids and 2-keto acids for initiation of insulin secretion. Journal of Biological Chemistry 257 6631-6633.

Lenzen S, Schmidt W \& Panten U 1985 Transamination of neutral amino acids and 2-keto acids in pancreatic B-cell mitochondria. Journal of Biological Chemistry $26012629-12634$.

Lu X, Schuurman HJ \& Borel JF 1994 Effect of rapamycin on islet xenograft survival. Transplantation Proceedings 26 1128-1129.

Maechler P \& Wollheim CB 2001 Mitochondrial function in normal and diabetic $\beta$-cells. Nature 414 807-812.

Malaisse WJ, Sener A, Malaisse-Legae F, Hutton JC \& Christophe J 1981 The stimulus-secretion coupling of amino acid-induced insulin release. Metabolic interaction of L-glutamine and 2-ketoisocaproate in pancreatic islets. Biochimica et Biophysica Acta 677 39-49.

Matschinsky FM 1996 Banting Lecture 1995. A lesson in metabolic regulation inspired by the glucokinase glucose sensor paradigm. Diabetes 45 223-241.

Matschinsky FM 2002 Regulation of pancreatic $\beta$-cell glucokinase. Diabetes 51 S394-S404.

McDaniel ML, Marshall CA, Pappan KL \& Kwon G 2002 Metabolic and autocrine regulation of the mammalian target of rapamycin by pancreatic $\beta$-cells. Diabetes 51 2877-2885. 
Meglasson MD \& Matschinsky FM 1984 New perspectives on pancreatic islet glucokinase. American Journal of Physiology 246 E1-E13.

Meglasson MD \& Matschinsky FM 1986 Pancreatic islet glucose metabolism and regulation of insulin secretion. Diabetes/Metabolism Reviews 2 163-214.

Nabe K, Fujimoto S, Shimodahira M, Kominato R, Nishi Y, Funakoshi S, Mukai E, Yamada Y, Seino Y \& Inagaki N 2006 Diphenylhydantoin suppresses glucose-induced insulin release by decreasing cytoplasmic $\mathrm{H}^{+}$ concentration in pancreatic islets. Endocrinology 147 2717-2727.

Nulton-Persson AC \& Szweda LI 2001 Modulation of mitochondrial function by hydrogen peroxide. Journal of Biological Chemistry $\mathbf{2 7 6}$ 23357-23361.

Östenson CG, Abdel-Halim SM, Rasschaert J, Malaisse-Lagae F, Meuris S, Sener A, Efendic S \& Malaisse WJ 1993 Deficient activity of FAD-linked glycerophosphate dehydrogenase in islets of GK rats. Diabetologia 36 722-726.

Radu RG, Fujimoto S, Mukai E, Takehiro M, Shimono D, Nabe K, Shimodahira M, Kominato R, Aramaki Y, Nishi Y et al. 2005 Tacrolimus suppresses glucose-induced insulin release from pancreatic islets by reducing glucokinase activity. American Journal of Physiology 288 E372-E380.

Richter OM \& Ludwig B 2003 Cytochrome $c$ oxidase - structure, function, and physiology of a redox-driven molecular machine. Reviews of Physiology, Biochemistry and Pharmacology 147 47-74.

Rorsman P 1997 The pancreatic $\beta$-cell as a fuel sensor: an electrophysiologist's viewpoint. Diabetologia 40 487-495.

Saito Y, Yoshida Y, Akazawa T, Takahashi K \& Niki E 2003 Cell death caused by selenium deficiency and protective effect of antioxidants. Journal of Biological Chemistry 278 39428-39434.

Sakai K, Matsumoto K, Nishikawa T, Suefuji M, Nakamaru K, Hirashima Y, Kawashima J, Shirotani T, Ichinose K, Brownlee M et al. 2003 Mitochondrial reactive oxygen species reduce insulin secretion by pancreatic $\beta$-cells. Biochemical and Biophysical Research Communications $\mathbf{3 0 0}$ 216-222.

Saunders RN, Metcalfe MS \& Nicholson ML 2001 Rapamycin in transplantation: a review of the evidence. Kidney International 59 3-16.

Scheffler IE 2008 Biogenesis of mitochondria and mitochondrial electron transfer and oxidative phosphorylation. In Mitochondria, edn 2, pp 60-297. Ed. IE Scheffler. Hoboken: John Wiley \& Sons, Inc.

Schieke SM, Phillips D, McCoy JP Jr, Aponte AM, Shen RF, Balaban RS \& Finkel T 2006 The mammalian target of rapamycin (mTOR) pathway regulates mitochondrial oxygen consumption and oxidative capacity. Journal of Biological Chemistry 281 27643-27652.

Schwab MA, Kölker S, van den Heuvel LP, Sauer S, Wolf NI, Rating D, Hoffmann GF, Smeitink JA \& Okun JG 2005 Optimized spectrophotometric assay for the completely activated pyruvate dehydrogenase complex in fibroblasts. Clinical Chemistry 51 151-160.

Sener A, Jijakli H, Zahedi Asl S, Courtois P, Yates AP, Meuris S, Best LC \& Malaisse WJ 2007 Possible role of carbonic anhydrase in rat pancreatic islets: enzymatic, secretory, metabolic, ionic, and electrical aspects. American Journal of Physiology 292 E1624-E1630.

Shapiro AM, Lakey JR, Ryan EA, Korbutt GS, Toth E, Warnock GL, Kneteman NM \& Rajotte RV 2000 Islet transplantation in seven patients with type 1 diabetes mellitus using a glucocorticoid-free immunosuppressive regimen. New England Journal of Medicine 343 230-238.

Simon N, Morin C, Urien S, Tillement JP \& Bruguerolle B 2003 Tacrolimus and sirolimus decrease oxidative phosphorylation of isolated rat kidney mitochondria. British Journal of Pharmacology 138 369-376.
Sipula IJ, Brown NF \& Perdomo G 2006 Rapamycin-mediated inhibition of mammalian target of rapamycin in skeletal muscle cells reduces glucose utilization and increases fatty acid oxidation. Metabolism $\mathbf{5 5}$ 1637-1644.

Taha C, Liu Z, Jin J, Al-Hasani H, Sonenberg N \& Klip A 1999 Opposite translational control of GLUT1 and GLUT4 glucose transporter mRNAs in response to insulin. Role of mammalian target of rapamycin, protein kinase B, and phosphatidylinositol 3-kinase in GLUT1 mRNA translation. Journal of Biological Chemistry 274 33085-33091.

Takahashi N, Kadowaki T, Yazaki Y, Ellis-Davies GC, Miyashita Y \& Kasai H 1999 Post-priming actions of ATP on $\mathrm{Ca}^{2+}$-dependent exocytosis in pancreatic $\beta$ cells. PNAS 96 760-765.

Takehiro M, Fujimoto S, Shimodahira M, Shimono D, Mukai E, Nabe K, Radu R G, Kominato R, Aramaki Y, Seino Y et al. 2005 Chronic exposure to $\beta$-hydroxybutyrate inhibits glucose-induced insulin release from pancreatic islets by decreasing NADH contents. American Journal of Physiology 288 E365-E371.

Teutonico A, Schena PF \& Di Paolo S 2005 Glucose metabolism in renal transplant recipients: effect of calcineurin inhibitor withdrawal and conversion to sirolimus. Journal of the American Society of Nephrology 16 3128-3135.

Tretter L \& Adam-Vizi V 2000 Inhibition of Krebs cycle enzymes by hydrogen peroxide: a key role of $\boldsymbol{\alpha}$-ketoglutarate dehydrogenase in limiting NADH production under oxidative stress. Journal of Neuroscience $\mathbf{2 0}$ 8972-8979.

Tsuruzoe K, Araki E, Furukawa N, Shirotani T, Matsumoto K, Kaneko K, Motoshima H, Yoshizato K, Shirakami A, Kishikawa H et al. 1998 Creation and characterization of a mitochondrial DNA-depleted pancreatic $\beta$-cell line: impaired insulin secretion induced by glucose, leucine, and sulfonylureas. Diabetes 47 621-631.

Welsh N, Eizirik DL, Bendtzen K \& Sandler S 1991 Interleukin-1 $\beta$-induced nitric oxide production in isolated rat pancreatic islets requires gene transcription and may lead to inhibition of the Krebs cycle enzyme aconitase. Endocrinology 129 3167-3173.

Yang ZC, Wang KS, Wu Y, Zou XQ, Xiang YY, Chen XP \& Li YJ 2009 Asymmetric dimethylarginine impairs glucose utilization via ROS/TLR4 pathway in adipocytes: an effect prevented by vitamin E. Cellular Physiology and Biochemistry 24 115-124.

Zhang N, Su D, Qu S, Tse T, Bottino R, Balamurugan AN, Xu J, Bromberg JS \& Dong HH 2006 Sirolimus is associated with reduced islet engraftment and impaired $\beta$-cell function. Diabetes 55 2429-2436.

Zhou YP \& Grill V 1995 Long term exposure to fatty acids and ketones inhibits B-cell functions in human pancreatic islets of Langerhans. Journal of Clinical Endocrinology and Metabolism 80 1584-1590.

Zickermann V, Kerscher S, Zwicker K, Tocilescu MA, Radermacher M \& Brandt U 2009 Architecture of complex I and its implications for electron transfer and proton pumping. Biochimica et Biophysica Acta 1787 574-583.

\section{Received in final form 16 September 2009 \\ Accepted 7 October 2009 \\ Made available online as an Accepted Preprint 7 October 2009}

